Nadwa : Jurnal Pendidikan Islam

Vol. 14, No.1 (2020)

Accredited by Ristekdikti based on Decree No. 51/E/KPT/2017

DOI: $10.21580 / \mathrm{nw} .2020 .14 .1 .5146$

\title{
The relevance of self-efficacy, perception, ICT ability, and teacher performance (Study on Islamic Teachers in Semarang, Indonesia)
}

\section{Ikhrom}

Walisongo State Islamic University Semarang

ikhrom@walisongo.ac.id

\section{Abstract}

The paper aimed to investigate the influence of teacher's self-efficacy and perception on his or her job to performance through ICT ability. The research is a quantitative description using path analysis methods. The population is 1500 . They are the Islamic religious teachers in Semarang, Central Java, Indonesia The researcher used Isaac \& Michael's table to determine the number of samples. Based on the table, the samples are 290. The Findings are the teachers' selfefficacy and perception greatly affect to their performance, while perception is also being the critical factor influences teachers to use ICT in the classroom, but self-efficacy is not the vital thing for teachers ability to use ICT. The finding recommends that self-efficacy and perception of Islamic teachers are vital aspects of the quality of performance. The use of ICT in the classroom is the critical variable for the quality of teacher performance.

Keywords: Islamic education; teacher performance; perception; self-efficacy; path analysis.

\section{Abstrak}

Penelitian ini bertujuan untuk mengetahui pengaruh self-efficacy dan persepsi guru pada pekerjaannya terhadap kinerja melalui kemampuan TIK. Jenis penelitian ini menggunakan deskriptif kuantitatif dengan metode analisis jalur (path analysis). Populasinya 1500 orang. Mereka adalah para guru Pendidikan Agama Islam di Semarang, Indonesia. Peneliti menggunakan tabel Isaac \& Michael untuk menentukan jumlah sampel. Berdasarkan tabel tersebut, sampelnya adalah 290. Temuannya adalah self-efficacy dan persepsi guru sangat berpengaruh terhadap kinerja mereka, sedangkan persepsi juga menjadi faktor kritis yang mempengaruhi guru untuk menggunakan TIK di kelas, tetapi self-efficacy bukan hal yang vital bagi kemampuan guru menggunakan TIK. Temuan ini merekomendasikan bahwa self-efficacy dan persepsi guru Islam merupakan aspek penting dari kualitas kinerja. Penggunaan TIK di kelas merupakan variabel penting untuk kualitas kinerja guru.

Kata kunci: pendidikan Islam; kinerja guru; persepsi; Efikasi Diri; analisis jalur. Kualitas kerja; 


\section{Introduction}

This study aims to reveal the influence of self-efficacy and teacher's perception of ICT ability (information, communication, and technology) and teacher's performance. The base of discussion is the reality in the field of how ICT ability and teacher performance, primarily Islamic religious teachers in Central Java, are relatively low. The ICT ability of Islamic religious teachers is mostly below average. Their ability to use computers as learning aids in class is still low. The low ability of this field of computer use turns out to be in line with the ability to develop teaching methods, using media, and developing teaching strategies in the classroom. In reality, the majority of Islamic religious teachers teach in conventional ways. Very few of them teach using contextual learning methods and strategies. The problem is whether self-efficacy and perception of the teacher's profession influence the ICT ability and the performance of Islamic religious teachers?

Many education experts have studied the close relationship between self-efficacy and perception related to one's performance. Heuer \& Keele 1 even specifically discussed the relationship between perceptions and attitudes and ways of working someone. The experts of psychology and education have studied the close relationship between self-efficacy, attitudes, and actions. Selfefficacy is a person's belief in his or her ability to carry out tasks.2 It indicates that self-efficacy and performance have a closeness

1 H Heuer and Steven W Keele, eds., Handbook of Perception and Action, Volume 2: Motor Skills (London: Academic Press, Inc., 1996), 53; Peter Avery, ed., Contrast in Phonology: Theory, Perception, Acquisition, Phonology and Phonetics (Berlin [u.a.]; Mouton de Gruyter, 2008), 56; Ron Owston, Dennis York, and Susan Murtha, "Student Perceptions and Achievement in a University Blended Learning Strategic Initiative," The Internet and Higher Education 18 (July 2013): 38-46, https://doi.org/10.1016/j.iheduc.2012.12.003.

2 Albert Bandura, Social Learning Theory (Englewood Cliffs, N.J: Prentice Hall, 1977). 
relationship. An expert has discussed in depth the closeness of the relationship between self-efficacy and one's performance.3 Even Wentzel \& Wigfield 4 firmly stated, self-efficacy affects motivation, achievement, and self-regulation. In line with these opinions, Bandura \& Jacobs5 have revealed that Self-efficacy has a strong influence on performance. Even Gaskil and Murphy6 found in their research that self-efficacy is the most decisive variable in a person's performance.

Based on the theory, self-efficacy and perception determined the commitment of teachers to improve their ability in the field of ICT and its performance. How to increase teacher self-efficacy for his profession is an important issue. In the research, Karel Kreijns7

3 Yu shan Chang et al., "Improving Creative Self-Efficacy and Performance through Computer-Aided Design Application," Thinking Skills and Creativity 31, no. September 2018 (2019): 103-11, https://doi.org/10.1016/j.tsc.2018.11.007; Toni Honicke and Jaclyn Broadbent, "The Influence of Academic Self-Efficacy on Academic Performance: A Systematic Review," Educational Research Review 17 (February 2016): 63-84, https://doi.org/10.1016/j.edurev.2015.11.002; Steven Randall Chesnut and Hansel Burley, "Self-Efficacy as a Predictor of Commitment to the Teaching Profession: A Meta-Analysis," Educational Research Review 15 (June 2015): 116, https://doi.org/10.1016/j.edurev.2015.02.001.

4 Kathryn R Wentzel and Allan Wigfield, eds., Handbook of Motivation at School, Educational Psychology Handbook Series (New York; London: Routledge, 2009), 36.

5 Albert Bandura, ed., Self-Efficacy in Changing Societies, Reprint (Cambridge: Cambridge Univ. Press, 1999).

6 Pamela J Gaskill and P Karen Murphy, "Effects of a Memory Strategy on Second-Graders' Performance and Self-Efficacy," Contemporary Educational Psychology 29, no. 1 (January 2004): 27-49, https://doi.org/10.1016/S0361476X(03)00008-0.

7 Karel Kreijns et al., "What Stimulates Teachers to Integrate ICT in Their Pedagogical Practices? The Use of Digital Learning Materials in Education," Computers in Human Behavior 29, no. 1 (January 2013): 217-25, https://doi.org/10.1016/j.chb.2012.08.008. 
found that the creation of a conducive working atmosphere is an essential variable in encouraging teachers to use ICT in classroom learning. The self-efficacy of a good teacher for his profession can encourage him to learn a lot of ICT and how to teach in the classroom. While the proficiency of teachers using ICT is directly proportional to the quality of learning in the classroom. 8

To analyze how the relationship patterns of the four variables, namely self-efficacy or/and teacher perceptions of ICT abilities and performance quality, were analyzed using path analysis. The researcher used Path analysis to find out the direct and indirect effects of variable $\mathrm{X}$ on variable $\mathrm{Y}$. The two questions are being the basis of all analyses are (1) do teacher self-efficacy and perceptions simultaneous or partial, both directly and indirectly influence ICT ability? And (2) do teacher self-efficacy and perceptions simultaneous or partial, both directly and indirectly influence performance through ICT ability?

\section{Performance is the Key Term.}

The quality performance of the teacher largely determines the quality of education. The quality of its performance determines teacher quality. Performance means accomplishment, execution, carrying out, working out of anything ordered, or carried out.9 Performance is about doing meaningful work in effective and

8 Shihkuan Hsu, "Who Assigns the Most ICT Activities? Examining the Relationship between Teacher and Student Usage," Computers \& Education 56, no. 3 (April 2011): 847-55, https://doi.org/10.1016/j.compedu.2010.10.026.

9 Regina M. Oliver, Joseph H. Wehby, and J. Ron Nelson, "Helping Teachers Maintain Classroom Management Practices Using a Self-Monitoring Checklist," Teaching and Teacher Education 51 (2015): 113-20, https://doi.org/10.1016/j.tate.2015.06.007; Justine Mercer, Bernard Barker, and Richard Bird, Human Resource Management in Education: Contexts, Themes, and Impact, Leadership for Learning Series (London; New York: Routledge, 2010), 55 . 
efficient ways.10 Performance is about how doing things, as well as what is doing. The performance involves two things: behavior and results. Behavior indicates competence, and results indicate to achievement. This theory of performance is in line with Armstrong's statement that performance is a function of capabilities as well as output (the achievement of objectives).11 Bandura 12 insists that performance is causally before outcomes. Bandura's quote indicates that there is no performance except an impact on achievement. Therefore, these two things are not enough to make someone's performance right. Excellent performance requires an environment, conditions, perceptions, and also the right motivation.

Galton and Simon13 say, performance is the result of the interaction of elements of motivation (m), ability (k), and perception ( $p$ ) in a person, so that formula of the performance is $\mathrm{P}=(\mathrm{mxk}+\mathrm{p})$. The meaning is, the more positive a person's perception of his job, coupled with his ability to relate to the job, and the motivation of his work is also good, the better the performance will be. The weakness of one of these elements will disrupt the performance.

The teacher's performance is a behavior produced by a teacher in carrying out her or his duties of teaching in the class. Teacher performance is a teachers' activity in carrying out their primary

10 Judith A Hale, Performance-Based Management: What Every Manager Should Do to Get Results (San Francisco: Pfeiffer, 2004), 2.

11 Angela Baron and Michael Armstrong, Human Capital Management: Achieving Added Value through People (London; Philadelphia: Kogan Page Ltd, 2007), 40.

12 Bandura, Social Learning Theory, 21.

13 James W Smither and Manuel London, eds., Performance Management: Putting Research into Action, The Professional Practice Series (San Francisco: Jossey-Bass, 2009), 61. 
tasks.14 The teacher's performance is daily working conditions and conditions. Teacher performance is closely related to the obligations of the teacher by the main activities, namely planning to learn, implementing learning, assessing learning outcomes, guiding and training students, and carrying out additional tasks inherent in the implementation of the main tasks of the teacher. Thus, teacher performance is a form of implementation of the main tasks and functions of the teacher as a whole.

To find out the quality of teacher performance, Armstrong 15 calls it, 'productive performance,' so we must know how to measure it. To measure teacher performance, people must know the dimensions of teacher performance. According to Michael D Jones, 16 teacher performance consists of five dimensions: (1) the quality of work and results of work, (2) speed and accuracy of work, (3) initiative in work, (4) ability to work, and (5) communication in work. The dimensions of work quality and work outcomes consist of several indicators: planning, mastery of teaching materials, management of the learning process, classroom management, and student achievement results. The dimensions of speed and accuracy of work consist of the use of media or learning resources, mastery of educational foundations, and planning of learning programs. The dimensions of initiative in work consist of class leadership, management of learning interactions, and implementation of learning outcomes assessments. The dimensions of workability consist of the application of variations in learning methods, and the implementation of remediation and enrichment.

14 Debra Hayes, ed., Teachers \& Schooling Making a Difference: Productive Pedagogies, Assessment and Performance, Studies in Education (Crows Nest: Allen \& Unwin, 2006), 127.

15 Armstrong, Performance Management, 43.

16 Michael D Jones, "Teacher Behavior under Performance Pay Incentives," Economics of Education Review 37 (December 2013): 148-64, https://doi.org/10.1016/j.econedurev.2013.09.005. 
The dimensions of communication include understanding and administering school administration and understanding and interpreting the results of research to improve the quality of learning.

The conclusion is many factors determine teacher performance. The quality of the surrounding factors determines the quality of teacher performance. These factors include competence, knowledge, attitude, confidence, motivation, and excellent communication skills. The latter is even the critical one because the quality of a teacher's performance is the quality of their communication. 17

\section{Self efficacy is a crucial variable to determine teachers' ICT ability and performance.}

Self-efficacy, not self-image, self-worth, or any other similar construct. Self-efficacy is the judgment of personal capability.18 It means self-efficacy refers to the belief of one's abilities, specifically the ability to meet the challenges and complete a task successfully. Self-efficacy is not just a person's belief in one's ability to carry out tasks that are on his shoulders. However, selfefficacy is a judgment of someone on his ability to plan and carry out, which leads to a particular goal.19 Self-efficacy is a person's belief that he can learn and do activities or work according to the desired level. Self-efficacy affects one's thoughts, feelings, and actions. Every person has a self-efficacy. Some have a high level of self-efficacy, and those who have a low level of self-efficacy.

17 Tony Swainston, Effective Teachers in Secondary Schools: A Reflective Resource for Performance Management, 2nd ed. (London: New York: Continuum International Pub. Group, 2008), 32, www.networkcontinuum.co.uk www.continuumbooks.com.

18 Albert Bandura, Self-Efficacy: The Exercise of Control, 1st Ed. (New York, NY, USA: W.H. Freeman \& Co., 1997), 11.

19 Bandura, Self-Efficacy in Changing Societies, 2. 
Thus, self-efficacy is not related to the skills one has, but rather about judgment on what person can do things with the skills possessed. Therefore, self-efficacy also helps determine how much effort a person will spend on an activity, and how long he will pursue his work even though there are many difficulties and challenges. People who have high self-efficacy will be calmer in facing difficulties and strikes in his work. He will continue to struggle to do the work to achieve success. While people who have low self-efficacy, they will effortlessly stop their work when they find many difficulties and obstacles. In short, self-efficacy is the belief that he or she can succeed.

The application of self-efficacy in academic studies is undoubtedly beneficial for improving the quality of education. Bandura20 states, "Perceived academic self-efficacy means personal judgments of one's capabilities to organize and execute courses of action to attain designated types of educational performances." The belief in self-efficacy is a crucial factor in the source of human action, what people think, believe, and feel affects how they act.21 Efficacy of beliefs influencing how people think, feel, motivate themselves, and act.22 Thus, self-efficacy can be as a control variable for commitment and teacher performance. Low or high self-efficacy can be as a control tool to determine the quality of a teacher's performance. Teachers who have low self-efficacy can indicate to low-performance quality. Conversely, teachers with high self-efficacy can be sure the quality of performance is outstanding. Gaskil \& Murphy's research findings conclude that

20 Bandura, 202.

21 Bandura, Self-Efficacy: The Exercise of Control, 22.

22 Bandura, Self-Efficacy in Changing Societies, 3. 
self-efficacy is the most dominant variable in determining teacher performance. 23

Self-efficacy is an essential aspect of influencing student learning24 and teacher performance. Many studies reveal the urgency of self-efficacy on teacher performance quality, 25 teacher creativity, 26 commitment teacher to his profession.27

23 Gaskill and Karen Murphy, "Effects of a Memory Strategy on SecondGraders' Performance and Self-Efficacy."

24 Anubha Rohatgi, Ronny Scherer, and Ove E Hatlevik, "The Role of ICT Self-Efficacy for Students' ICT Use and Their Achievement in a Computer and Information Literacy Test," Computers \& Education 102 (November 2016): 103-16, https://doi.org/10.1016/j.compedu.2016.08.001.

25 Honicke and Broadbent, "The Influence of Academic Self-Efficacy on Academi"; Chang et al., "Improving Creative Self-Efficacy and Performance through Computer-Aided Design Application"; Matthew L Bernacki, Timothy J Nokes-Malach, and Vincent Aleven, "Examining Self-Efficacy during Learning: Variability and Relations to Behavior, Performance, and Learning," Metacognition and Learning 10, no. 1 (April 2015): 99-117, https://doi.org/10.1007/s11409-014-9127-x.

26 Meera Komarraju and Dustin Nadler, "Self-Efficacy and Academic Achievement: Why Do Implicit Beliefs, Goals, and Effort Regulation Matter?," Learning and Individual Differences 25 (June 2013): 67-72, https://doi.org/10.1016/j.lindif.2013.01.005.

27 Chesnut and Burley, "Self-Efficacy as a Predictor of Commitment to The"; Sungtaek Lim and Sungmin Eo, "The Mediating Roles of Collective Teacher Efficacy in the Relations of Teachers' Perceptions of School Organizational Climate to Their Burnout," Teaching and Teacher Education 44 (November 2014): 138-47, https://doi.org/10.1016/j.tate.2014.08.007; Einar M Skaalvik and Sidsel Skaalvik, "Teacher Self-Efficacy and Teacher Burnout: A Study of Relations," Teaching and Teacher Education 26, no. 4 (May 2010): 1059-69, https://doi.org/10.1016/j.tate.2009.11.001; Mona Tabatabaee Yazdi, Khalil Motallebzadeh, and Hamid Ashraf, "The Role of Teacher's Self-Efficacy as a Predictor of Iranian EFL Teacher's Burnout," Journal of Language Teaching and Research 5, no. 5 (September 2014): 1198-1204, https://doi.org/10.4304/jltr.5.5.1198-1204. 
Many studies on the relationship of self-efficacy with teachers' ICT ability and performance. The teacher's mastering on ICT in the learning process determines the quality of achievement of the students in his class. Thus the findings of the study entitled "Is the way they use it?: Teacher, ICT, and Achievement".28 Research on ICT use and student achievement was also carried out by Cunska and Savicka29 with the title "Use of ICT Teaching-Learning Methods for making School Math Blossom". Although the focus of the study does not directly link ICT skills to achievement, the ultimate goal of the research is ICT empowerment in the learning process can make the classroom atmosphere pleasant and refreshing. Difficult mathematical material can be easily understood by students, thanks to using ICT.

Next, how is the relationship between self-efficacy and teacher performance? The definition of self-efficacy has clearly stated, self-efficacy is the belief in our ability to succeed. People who believe that they can succeed have the readiness to face all obstacles and obstacles in carrying out their profession. He even has a sense of crisis that success in work requires sacrifice. People like this certainly do not give up easily when obstacles and difficulties arise. Theoretically, the relationship between the effect of self-efficacy and performance is powerful. Besides, research has also proven the strong influence of self-efficacy on performance. Research of Gaskil dan Murphy30 concluded that self-efficacy is the dominant variable for performance. A similar conclusion is also

28 Simona Lorena Comi et al., "Is It the Way They Use It? Teachers, ICT and Student Achievement," Economics of Education Review 56 (February 2017): 24-39, https://doi.org/10.1016/j.econedurev.2016.11.007.

29 Aija Cunska and Inga Savicka, "Use of ICT Teaching-Learning Methods Make School Math Blossom," Procedia - Social and Behavioral Sciences 69 (December 2012): 1481-88, https://doi.org/10.1016/j.sbspro.2012.12.089.

30 Gaskill and Karen Murphy, "Effects of a Memory Strategy on SecondGraders' Performance and Self-Efficacy." 
coming from other research with a focus on 'the relationship of selfefficacy and performance'.31

\section{Perception is a vital thing for the teacher.}

Perception is a psychological factor that has essential roles in influencing individuals both in behaving and acting. Perception is not merely a reaction to outside stimulation but a process of creation. 32 The definition of this perception changes the current view of the meaning of perception. Until now, perceptions are only reactions to external stimulation. This understanding provides an understanding that perception is a process of creation. Niedenthal 33 defines that perception is the transformation of sensations caused by impinging stimulus into an internal representation of that stimulus.

Perception consists of two parts. The basis of dividing is the quality of attitude (affective qualities).34 First, perception in the

31 Honicke and Broadbent, "The Influence of Academic Self-Efficacy on Academi"; Chesnut and Burley, "Self-Efficacy as a Predictor of Commitment to The"; Krista Althauser, "Job-Embedded Professional Development: Its Impact on Teacher Self-Efficacy and Student Performance," Teacher Development 19, no. 2 (April 2015): 210-25, https://doi.org/10.1080/13664530.2015.1011346.

32 Ralph D Ellis and Natika Newton, eds., Consciousness \& Emotion: Agency, Conscious Choice, and Selective Perception, Consciousness \& Emotion Book Series (Amsterdam; Philadelphia: John Benjamins Publishing Company, 2005); Kadriye Ercikan and Wolff-Michael Roth, eds., Generalizing from Educational Research: Beyond Qualitative and Quantitative Polarization (New York: Routledge, 2009), 128.

33 Paula M Niedenthal and Shinobu Kitayama, eds., The Heart's Eye, Emotional Influence in Perception and Attention (San Diego, California: Academic Press, Inc., 1994), 4-7.

34 Paula M Niedenthal (Editor), The Heart's Eye : Emotional Influences in Perception and Attention (San Diego, California: Academic Press, Inc., 1994), 25. 
form of attitude (perception becomes effective). Second, creative perception. The first one is only talking about attitude, 35 but the second is continued to create something. The Good' theory of perception is the kind of perception that impact on individual behavior. This meaning is in line with Rookes \& Willson's definition.36 Perception is a process that makes people choose, organize, and interpret stimuli received into a meaningful and complete picture of the world. This kind of perception is the object of study by many researchers. The influence of teacher perceptions proved to have a positive impact on performance. Even based on the finding of the research, the teacher's positive perception can improve his or her performance. 37 They recommend, improving the school can not deny the teacher's perception. Perception will help them and finally make decisions to behave and act. The theory states that perception is part of the information processing system. It is a complex phenomenon that provides higher-order processes such as creative choices. 38

A teacher who has a positive perception and thoughts of his work, his or her feelings will be calm because he or she enjoys the teaching profession. Her or his behavior is steady and positive. The appearance is also convincing. Some theories support the relationship between teacher perceptions and performance. The

35 Justin Good, Wittgenstein and The Theory of Perception (London; New York: Continuum, 2006), 102.

36 Paul Rookes and Jane Willson, Perception: Theory, Development, and Organisation, Routledge Modular Psychology (London; New York: Routledge, 2000), 146.

37 Mary Webb and Roshaunda Thomas, "Teachers' Perceptions of Educators' and Students' Role in Closing the Achievement Gap” 25, no. 3 (2015): 8 .

38 Markus Raab et al., eds., Performance Psychology: Perception, Action, Cognition, and Emotion (London: Elsevier Academic Press, 2016), 4. 
research finding of Campbell et al.39 has proven that perception affects performance. The four studies recommended that perceptions significantly influence teacher performance.

The following are some studies that recommend that perceptions significantly influence the ability of a teacher to use ICT in the learning process. First, the research conducted by Bas, Kubiatko, and Sunbul40, the results stated that the teacher perceptions are very significant towards the enthusiasm of teachers in using ICT in the teaching-learning process. Second, research of Mura and Diamantini41 with the same focus also found the conclusions that in line with the first study, the teachers' positive perception of the teaching profession positively affected the use of ICT in the teaching-learning process. Third, this study conducted by Kopcha42 resulted that ICT integration in the teaching and

39 Conni Campbell et al., "Beginning Teachers' Perceptions of the California Teaching Performance Assessment (TPA)," Teacher Education Quarterly 43, no. 2 (2016): 51; Raab et al., Performance Psychology; Owston, York, and Murtha, "Student Perceptions and Achievement in a University Blended Learning Strategic Initiative"; Sarah Benes et al., "Teachers' Perceptions of Using Movement in the Classroom," The Physical Educator 73, no. 1 (2016), https://doi.org/10.18666/TPE-2016-V73-I1-5316.

40 Gökhan Baş, Milan Kubiatko, and Ali Murat Sünbül, "Teachers' Perceptions towards ICTs in Teaching-Learning Process: Scale Validity and Reliability Study," Computers in Human Behavior 61 (August 2016): 176-85, https://doi.org/10.1016/j.chb.2016.03.022.

${ }_{41}$ Giulia Mura and Davide Diamantini, "The Use and Perception of ICT among Educators: The Italian Case," Procedia - Social and Behavioral Sciences 141 (August 2014): 1228-33, https://doi.org/10.1016/j.sbspro.2014.05.211.

42 Theodore J Kopcha, "Teachers' Perceptions of the Barriers to Technology Integration and Practices with Technology under Situated Professional Development," Computers \& Education 59, no. 4 (December 2012): 1109-21, https://doi.org/10.1016/j.compedu.2012.05.014; Cynthia Reyes and Kathleen Brinegar, "Lessons Learned: Using the Literacy Histories of Education Students to Foster Empathy," Teaching and Teacher Education 59 (October 2016): 327-37, https://doi.org/10.1016/j.tate.2016.06.014. 
learning process was only able to be carried out by teachers who had a positive perception of their profession.

\section{Teacher self-efficacy and perception are dual power for teachers' empowerment.}

Combining the belief in one's capabilities and perception will be the productive power for teachers' performance. Miller et al.43; Kung 44 dan Chong et al.45 has proven through their research that self-efficacy and perception simultaneously form an effective teacher in carrying out their duties. Even with these twin power, their teaching makes students eager to learn until their achievements increase. However, no much research on the relationship between self-efficacy and perceptions with ICT abilities and teacher performance. Research on self-efficacy and perception is found together, but not much. Miller et al. \& Kung proved that self-efficacy and perception both simultaneously influence teacher performance.

43 Angela D Miller, Erin M Ramirez, and Tamera B Murdock, "The Influence of Teachers' Self-Efficacy on Perceptions: Perceived Teacher Competence and Respect and Student Effort and Achievement," Teaching and Teacher Education 64 (May 2017): 260-69, https://doi.org/10.1016/j.tate.2017.02.008.

44 Hsin-Yi Kung, "Perception or Confidence? Self-Concept, Self-Efficacy and Achievement in Mathematics: A Longitudinal Study," Policy Futures in Education 7, no. 4 (August 2009): 387-98, https://doi.org/10.2304/pfie.2009.7.4.387.

45 Wan Har Chong et al., "Student Perceptions of Self-Efficacy and Teacher Support for Learning in Fostering Youth Competencies: Roles of Affective and Cognitive Engagement," Journal of Adolescence 68 (October 2018): 1-11, https://doi.org/10.1016/j.adolescence.2018.07.002. 
The explanation confirms that the relationship between selfefficacy, perception, ICT ability, and teacher performance had theoretical support and empirical data. It is thus significant for the verificative research design. Merten 46 insisted the use of path analysis is to test a causal theoretical model. Displaying the previous research findings are mostly needed.

\section{Research Method}

This research is an ex post facto type of research. Ex post facto means after the fact. 47 This study traces events that have occurred based on respondents' responses, with a quantitative approach. Data was collected using a questionnaire instrument distributed to respondents. Determining respondents through sampling techniques. The sampling technique uses random sampling. The research population was all Islamic religious teachers in Semarang City that come from elementary school, junior high school, and senior high school. From the data obtained from the Head of the Ministry of Religion in Semarang, there were 1500 Islamic religious teachers. The size of the study sample was determined using the Isaac \& Michael table. Based on the table, the sample size is obtained with a 5\% error rate at the $95 \%$ confidence level to a population of 290.48 Furthermore, to determine who the respondents were 300 people, the researcher decided to divide equally according to the level of education, so that 100 Islamic religious teachers represented each level of education. 100 from

46 Donna M Mertens, Research and Evaluation in Education and Psychology: Integrating Diversity with Quantitative, Qualitative, and Mixed Methods, 3rd ed (Los Angeles: Sage, 2010), 167.

47 Louis Cohen, Lawrence Manion, and Keith Morrison, Research Methods in Education, 5th ed (London ; New York: RoutledgeFalmer, 2000), 205.

48 Patricia Leavy, Research Design: Quantitative, Qualitative, Mixed Methods, Arts-Based and Community-Based Participatory Research Approaches (New York, NY, USA: The Guilford Press, 2017). 
elementary school, 100 from junior high school, and 100 from senior high school.

The collected data is analyzed using path analysis. The use of path analysis is to test a causal theoretical model. Path analysis is not a method used to find causes but to find an explanation of the patterns of direct and indirect relations of a causal model. The basis of cause and effect relationship pattern is theoretical considerations and the knowledge of researchers.49 Path analysis to analyze the pattern of causal relationships between several exogenous variables towards endogenous variables both directly and indirectly, simultaneously or partially. The path analysis model is only suitable for data that meets the assumptions that apply to regression analysis. The assumptions are including the normality, linearity, and homogeneity. As Teoso stated, "the assumptions of linearity, normality of errors, and homogeneity are generally assessed by graphical means, but more formal assessments can also be made."

Path analysis is to analyze the pattern of causal relationships between several exogenous variables towards endogenous variables both directly and indirectly, simultaneously or partially. The calculation of statistics is performed using SPSS 21. Based on the theoretical framework, that the carrying out path analysis through two steps, namely: (1) do teacher self-efficacy, perception simultaneous or partial influence ICT ability?; (2) do teacher selfefficacy and perceptions simultaneous or partial both directly and indirectly influence performance through ICT ability?

49 Elazar J Pedhazur, Multiple Regression in Behavioral Research: Explanation and Prediction, 3rd ed (Australia; Canada; United Kingdom: Thomson Learning, Inc., 1997), 581.

50 Timothy Teo, ed., Handbook of Quantitative Methods for Educational Research (Rotterdam: SensePublishers, 2013), 85. 
Furthermore, the discussion of the results of the study was carried out by confirming field data with theoretical studies as well as theoretical frameworks. The next step is to decompose the correlation to calculate the value of the combined effect, partial effect, direct and indirect influence, total influence, the influence of other factors. Hypothesis testing is by examining the limits of acceptance-rejection of the level of statistical significance and the result of the path coefficient.51

\section{Findings and Discussions}

First, path analysis is a stepwise regression analysis that test analysis requirements and is often called assumption testing. Cohen52 emphasized that the path analysis model can be only applied to data meets the classical assumptions include a test of linearity, normality, and homogeneity.

The linearity test is aimed to determine whether two variables have a relationship that is linear or not significantly. If there are two variables $\mathrm{X}$ and $\mathrm{Y}$ are not linear, then it is not possible to make a prediction. From the results of testing the linearity of $X_{1}, X_{2}, X_{3}$ on the $Y$ variable obtained data, that all data $X_{1}, X_{2}$, and $X_{3}$ against $\mathrm{Y}$ are linear. The linearity test is by ANOVA table. The criterium is if the sig scores lower than 0,05 , so the data are linear.

ANOVA Table

\begin{tabular}{|c|c|c|c|c|c|c|c|}
\hline & & & $\begin{array}{l}\text { Sum of } \\
\text { Squares }\end{array}$ & df & Mean Square & $\mathrm{F}$ & Sig. \\
\hline \multirow{5}{*}{$\begin{array}{l}\text { Performance * Self- } \\
\text { Efficacy }\end{array}$} & \multirow[t]{3}{*}{ Between Groups } & (Combined) & 27541.481 & 57 & 483.184 & 4.942 & .000 \\
\hline & & Linearity & 10108.735 & 1 & 10108.735 & 103.396 & .000 \\
\hline & & Deviation from Linearity & 17432.746 & 56 & 311.299 & 3.184 & .000 \\
\hline & \multicolumn{2}{|l|}{ Within Groups } & 22681.898 & 232 & 97.767 & & \\
\hline & \multicolumn{2}{|l|}{ Total } & 50223.379 & 289 & & & \\
\hline
\end{tabular}

ANOVA Table

\begin{tabular}{|c|c|c|c|c|c|c|c|}
\hline & & & $\begin{array}{l}\text { Sum of } \\
\text { Squares }\end{array}$ & df & Mean Square & $\mathrm{F}$ & Sig. \\
\hline \multirow[t]{5}{*}{ Performance *ICT Ability } & \multirow[t]{3}{*}{ Between Groups } & (Combined) & 14139.162 & 42 & 336.647 & 2.304 & .000 \\
\hline & & Linearity & 2618.167 & 1 & 2618.167 & 17.922 & .000 \\
\hline & & Deviation from Linearity & 11520.995 & 41 & 281.000 & 1.923 & .001 \\
\hline & \multicolumn{2}{|l|}{ Within Groups } & 36084.217 & 247 & 146.090 & & \\
\hline & \multicolumn{2}{|l|}{ Total } & 50223.379 & 289 & & & \\
\hline
\end{tabular}


From the table shows that the significant score in linearity in the three tables is 0,000 . The significance is less than 0.05 , and the conclusion that there is a linear relationship between the selfefficacy variable, perception, ICT ability, and performance.

The second assumption test is the normality test. Data normality test is used to determine the standard frequency distribution of research data. If the distribution of data is not standard, the results of the statistical analysis are less able to describe the characteristics of the population.

Test Statistics

\begin{tabular}{|l|r|r|r|r|}
\hline & Self-Efficacy & Perception & ICT Ability & Performance \\
\hline Chi-Square & $140.400^{\mathrm{a}}$ & $156.648^{\mathrm{b}}$ & $259.510^{\mathrm{C}}$ & $156.897^{\mathrm{d}}$ \\
df & 57 & 62 & 42 & 53 \\
Asymp. Sig. & .000 & .000 & .000 & .000 \\
\hline
\end{tabular}

a. 0 cells $(0.0 \%)$ have expected frequencies less than 5 . The minimum expected cell frequency is 5.0.

b. 63 cells $(100.0 \%)$ have expected frequencies less than 5 . The minimum expected cell frequency is 4.6 .

c. 0 cells $(0.0 \%)$ have expected frequencies less than 5 . The minimum expected cell frequency is 6.7 .

d. 0 cells $(0.0 \%)$ have expected frequencies less than 5 . The minimum expected cell frequency is 5.4 .

The criterium, distribution of data standard if Asymp. Sig. > than 0.05. From the table above, it shows that the Asymp. Sig score of the four variables is smaller than 0.05 , which means that the data distribution of the population of self-efficacy, perception, ICT, and performance data is normal. 
The homogeneity test is to evaluate whether each residual error for the independent variables is known to have the same variance. If the variance is different, it will cause the linear regression equation produced is no longer useful to make a prediction. The homogeneity test is carried out using a histogram, as illustrated below.

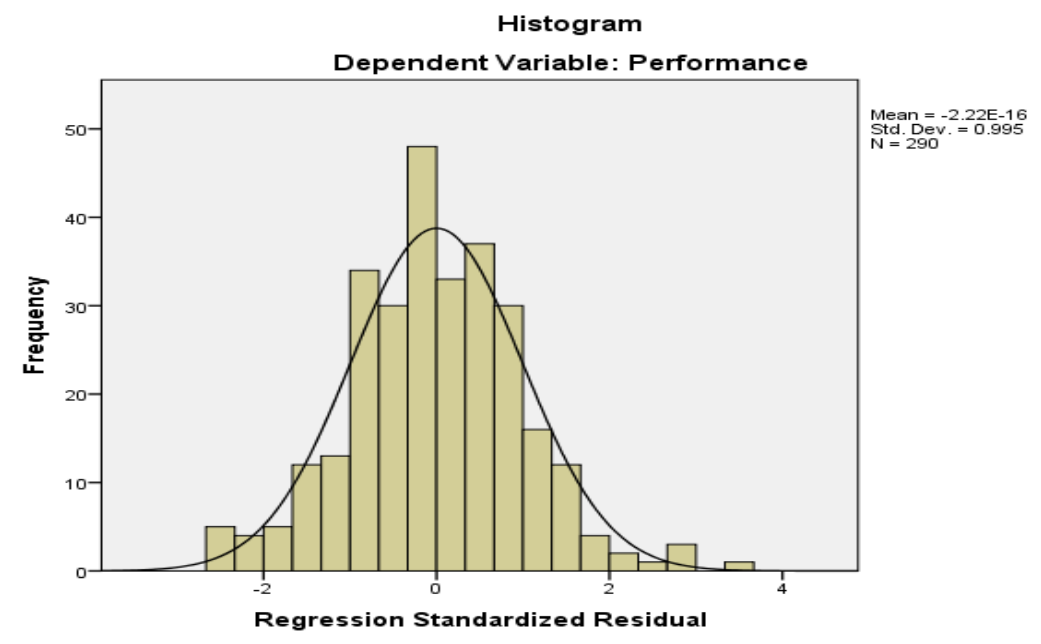

Picture 1: Histogram of homogeneity

The interpretation of the histogram in the picture above that the variant data from the population is homogeneous. Data shows that the distribution of data forms a standard curve. That explains the research data has met the requirements of homogeneity. Then research can be carried out because homogeneity is one of the requirements for a path analysis model.

Second, after checking the assumption, the discussion continued with an examination of the path analysis of Sub Structure 1: do teacher self-efficacy and perceptions simultaneous or partial, both directly and indirectly influence ICT ability? 
The basis of discussion of substructure one is the results of the analysis using the SPSS method as below.

Model Summary

\begin{tabular}{|l|l|r|r|r|}
\hline Model & $\mathrm{R}$ & R Square & $\begin{array}{c}\text { Adjusted R } \\
\text { Square }\end{array}$ & $\begin{array}{c}\text { Std. Error of } \\
\text { the Estimate }\end{array}$ \\
\hline 1 & $.364^{\mathrm{a}}$ & .132 & .126 & 10.39271 \\
\hline
\end{tabular}

a. Predictors: (Constant), Perception, Self-Efficacy

\begin{tabular}{|c|c|c|c|c|c|c|}
\hline \multicolumn{7}{|c|}{ ANOVA ${ }^{a}$} \\
\hline & & $\begin{array}{l}\text { Sum of } \\
\text { Squares }\end{array}$ & df & Mean Square & $\mathrm{F}$ & Sig. \\
\hline \multirow[t]{3}{*}{1} & Regression & 4720.290 & 2 & 2360.145 & 21.851 & $.000^{b}$ \\
\hline & Residual & 30998.431 & 287 & 108.008 & & \\
\hline & Total & 35718.721 & 289 & & & \\
\hline
\end{tabular}

a. Dependent Variable: ICT Ability

b. Predictors: (Constant), Perception, Self-Efficacy

Coefficients $^{\text {a }}$

\begin{tabular}{|c|c|c|c|c|c|c|}
\hline \multirow{2}{*}{\multicolumn{2}{|c|}{ Model }} & \multicolumn{2}{|c|}{ Unstandardized Coefficients } & \multirow{2}{*}{$\begin{array}{c}\begin{array}{c}\text { Standardized } \\
\text { Coefficients }\end{array} \\
\text { Beta } \\
\end{array}$} & \multirow[b]{2}{*}{ t } & \multirow[b]{2}{*}{ Sig. } \\
\hline & & $B$ & Std. Error & & & \\
\hline \multirow[t]{3}{*}{1} & (Constant) & 72.323 & 6.803 & & 10.632 & .000 \\
\hline & Self-Efficacy & .049 & .042 & .067 & 1.156 & .249 \\
\hline & Perception & .220 & .038 & .337 & 5.802 & .000 \\
\hline
\end{tabular}

a. Dependent Variable: ICT Ability

In the summary model table, the coefficient of determination (Adjusted R2) is 0.189. The use of score is the basis for determining the residual coefficient score of the sub-structure path analysis 1 . The formula for the residual coefficient is $\sqrt{ } 1-\mathrm{R}^{2}$. The results obtained are $\sqrt{ } 1-0.126=0,935(93.5 \%)$. This score is included in the multiple regression equation analysis of the sub-structure path I $(X 3=$ p31 X1 + p32 X2 + p3.e1). After filling out the formula, the results are $\left(X_{3}=0.067+0.337+0.935\right)$. That is, self-efficacy influences ICT ability variable (0.067), perceptions (0.142), and several residual variables not included in the research model of 0.935 , or $93.5 \%$ influenced the rest, while the table shows that $\mathrm{F}$ 
table (Anova Table) has a score of 21,851 with the significance level of $0,000 \geq 0.05$. The meaning, self-efficacy, and perception together significantly influence ICT ability, while partially selfefficacy does not significantly influence ICT, while perceptions have a significant effect.

Then to be easily understood, the above explanation can be summarized in the form of substructure one coefficient table as follows.

\begin{tabular}{ccccl}
\hline $\begin{array}{c}\text { Independent } \\
\text { Variable }\end{array}$ & $\begin{array}{c}\text { Symb } \\
\text { ol }\end{array}$ & $\begin{array}{c}\text { Coefficie } \\
\text { nt } \boldsymbol{\beta}\end{array}$ & Sig. & Statu \\
\hline $\begin{array}{c}\text { Self- } \\
\text { Efficacy }\end{array}$ & P31 & 0,067 & 0,24 & $\begin{array}{l}\text { Non- } \\
\text { significanc } \\
\text { elf }\end{array}$ \\
\hline Percepti & P32 & 0,337 & 0,00 & $\begin{array}{l}\text { Significan } \\
\text { ce }\end{array}$ \\
on & & & 0 & \multicolumn{2}{l}{\begin{tabular}{l} 
ce \\
\hline
\end{tabular}}
\end{tabular}

Third, the discussion continued with an examination of the path analysis of Sub Structure 2: do teacher self-efficacy and perceptions simultaneous or partial, both directly and indirectly influence performance through ICT ability?

The essential discussion of substructure two is the results of the analysis using the SPSS method as below.

Model Summary

\begin{tabular}{|l|l|r|r|r|}
\hline Model & R & R Square & $\begin{array}{c}\text { Adjusted R } \\
\text { Square }\end{array}$ & $\begin{array}{c}\text { Std. Error of } \\
\text { the Estimate }\end{array}$ \\
\hline 1 & $.633^{\mathrm{a}}$ & .401 & .394 & 10.25901 \\
\hline
\end{tabular}

a. Predictors: (Constant), ICT Ability, Self-Efficacy, Perception

ANOVA $^{\mathrm{a}}$

\begin{tabular}{|ll|l|r|r|r|c|}
\hline Model & & $\begin{array}{l}\text { Sum of } \\
\text { Squares }\end{array}$ & df & Mean Square & F & Sig. \\
\hline 1 & Regression & 20122.665 & 3 & 6707.555 & 63.731 & $.000^{\mathrm{b}}$ \\
& Residual & 30100.714 & 286 & 105.247 & & \\
& Total & 50223.379 & 289 & & & \\
\hline
\end{tabular}

a. Dependent Variable: Performance

b. Predictors: (Constant), ICT Ability, Self-Efficacy, Perception 
Coefficients $^{a}$

\begin{tabular}{|c|c|c|c|c|c|c|}
\hline \multirow{2}{*}{\multicolumn{2}{|c|}{ Model }} & \multicolumn{2}{|c|}{ Unstandardized Coefficients } & \multirow{2}{*}{$\begin{array}{c}\begin{array}{c}\text { Standardized } \\
\text { Coefficients }\end{array} \\
\text { Beta } \\
\end{array}$} & \multirow[b]{2}{*}{$t$} & \multirow[b]{2}{*}{ Sig. } \\
\hline & & $\mathrm{B}$ & Std. Error & & & \\
\hline \multirow[t]{4}{*}{1} & (Constant) & 69.320 & 7.928 & & 8.744 & .000 \\
\hline & Self-Efficacy & .257 & .042 & .298 & 6.160 & .000 \\
\hline & Perception & .363 & .040 & .468 & 9.168 & .000 \\
\hline & ICT Ability & .011 & .058 & .009 & .181 & .857 \\
\hline
\end{tabular}

a. Dependent Variable: Performance

The table of the model summary shows that the determination coefficient score is 0,394 . The score is basic in determining the residual coefficient score of path analysis of substructure two. the key of the residual coefficient is $\sqrt{1}-\mathrm{R}^{2}$ and the result is $\sqrt{1}-$ $0,394=0,778(78,8 \%)$. The score will be the basis of the multiple regression equation of path analysis of substructure two $\left(\mathrm{Y}=\mathrm{py}_{1}\right.$ $\mathrm{X}_{1}+\mathrm{py}_{2} \mathrm{X}_{2}+\mathrm{py}_{3} \mathrm{X}_{3}+$ py.e $\mathrm{e}_{2}$. After filling out the formula, the results are $(Y=0,298+0,468+0,009+0,778)$. That is, selfefficacy (0.298), perceptions (0.468), ICT ability $(0,009)$ influenced the variation in performance variable and several residual variables not included in the research model of 0.778 , or 78.8\% influenced the rest, while $\mathrm{F}$ table (Anova Table) has a score of 63.731 at the significance level of $0,000 \geq 0.05$. The meaning, self-efficacy, perception, and ICT ability together significantly influence performance, while partially ICT ability does not significantly influence performance, while self-efficacy and perceptions have a significant effect. 
Then to be easily understood, the above explanation can be summarized in the form of substructure two coefficient tables as follows.

\begin{tabular}{lcccl}
\hline $\begin{array}{c}\text { Independent } \\
\text { Variable }\end{array}$ & Symbol & $\begin{array}{c}\text { Coefficient } \\
\boldsymbol{\beta}\end{array}$ & Sig. & Status \\
\hline Self-Efficacy & Py1 & 0,298 & 0,000 & Significant \\
\hline Perception & Py2 & 0,468 & 0,000 & Significant \\
\hline ICT Ability & Py3 & 0,009 & 0,857 & $\begin{array}{l}\text { Non- } \\
\text { significant }\end{array}$ \\
\hline
\end{tabular}

The explanation of path analysis from sub-structures one and two, which contain the path coefficients above, will be the basis for discussing the research findings, and the formula of substructure one and two as follow.

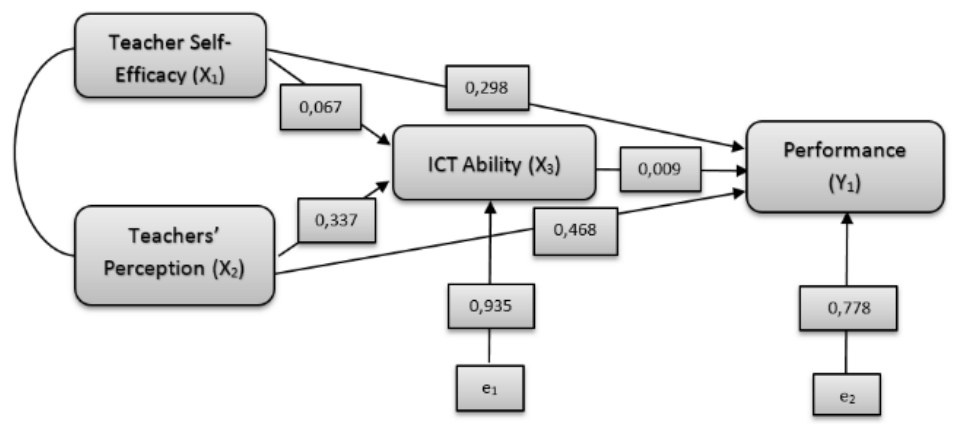

Picture 2: Combined Results of Analysis of Sub Structures 1 and 2, and Beta Values

To find out the shape of the causal relationship of exogenous variables to the endogenous variable as a whole, a summary of the coefficient scores of the analysis of sub-structure one and substructure two are in the following table. 


\begin{tabular}{ccccl}
\hline $\begin{array}{c}\text { Relationship } \\
\text { Pattern }\end{array}$ & Symbol & $\begin{array}{c}\text { Coefficient } \\
\mathbf{p}\end{array}$ & Sig. & Status \\
\hline $\mathrm{X} 1 \rightarrow \mathrm{X} 3$ & $\mathrm{P} 31$ & 0,067 & 0,249 & $\begin{array}{l}\text { Non- } \\
\text { significant }\end{array}$ \\
\hline $\mathrm{X} 2 \rightarrow \mathrm{X} 3$ & $\mathrm{P} 32$ & 0,337 & 0,000 & Significant \\
\hline $\mathrm{X} 1 \rightarrow \mathrm{Y}$ & Py1 & 0,298 & 0,000 & Significant \\
\hline $\mathrm{X} 2 \rightarrow \mathrm{Y}$ & Py2 & 0,468 & 0,000 & Significant \\
\hline $\mathrm{X} 3 \rightarrow \mathrm{Y}$ & Py3 & 0,009 & 0,857 & $\begin{array}{l}\text { Non- } \\
\text { significant }\end{array}$ \\
\hline
\end{tabular}

The filling of path coefficient scores (p coefficients) in the combined table above is in the path diagram model provided that variables with a sig score greater than 0.05 (not significant) are by removing arrow at the coefficient so that the image of a revised empirical model as follows.

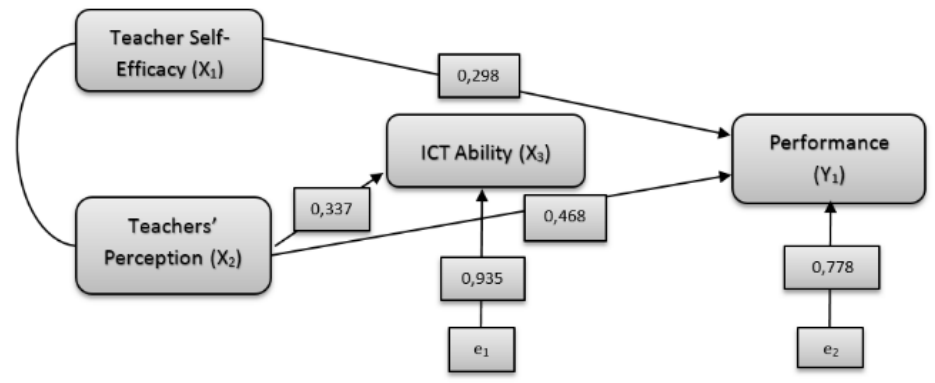

Picture 3: Empirical Revised Model and Beta $(\beta)$ Value

Picture 3: Empirical Revised Model and Beta $(\beta)$ Value, some changes found. First, deleting the arrow from $X_{1}$ to $X_{3}$, because it is not significant. Second, deleting the arrow from $\mathrm{X}_{3}$ to $\mathrm{Y}$ because it is also not significant.

Then is the process of decomposition of correlations between exogenous variables with endogenous variables. Decomposition 
aims to find the magnitude of the coefficient on the pattern of direct influence (DE) and indirect influence (ID). The calculation of DE and ID quantities involve exogenous variables on endogenous variables. Decomposition is only done at a significant path coefficient - removal of arrows in the revised model above for the benefit of the correlation decomposition process.

The process of decomposition of correlation is carried out based on the detailed equations of the substructure two-equation called substructure $3,4,5$.

1. $\mathrm{Y}=\mathrm{py} 1 \mathrm{X} 1+\mathrm{py} 3 \mathrm{X} 3+\mathrm{e} 3$

2. $Y=p y 2 X 2+p y 3 X 3+e 4$

3. $\mathrm{Y}=\mathrm{py} 3 \mathrm{X} 3+\mathrm{e} 5$

Based on the three equations, the following results are obtained.

First, the pattern of the relationship between the variable selfefficacy $\left(\mathrm{X}_{1}\right)$ on the performance variable $(\mathrm{Y})=$ py1 $\mathrm{X} 1+$ py $3 \mathrm{X}_{3}+$ e3. $\mathrm{DE}=$ py1 is significant $(0.30)$, while $\mathrm{IE}=$ not significant. From the results of the decomposition, it shows that the pattern of the relationship between exogenous self-efficacy $\left(\mathrm{X}_{1}\right)$ and endogenous performance variables $(\mathrm{Y})$ does not have an indirect relationship pattern, but has a significant direct relationship pattern, $\mathrm{DE}=$ py1 (0.30).

Second, the pattern of relations between perception variables $\left(\mathrm{X}_{2}\right)$ with performance variables $(\mathrm{Y}) . \mathrm{Y}=\mathrm{py} 2 \mathrm{X}_{2}+\mathrm{py} 3 \mathrm{X} 3+\mathrm{e} 4$. $\mathrm{DE}=$ significant (0.47), IE is also significant (0.34). From the results of the decomposition, it shows that the relationship between the exogenous variables of perception $\left(\mathrm{X}_{2}\right)$ and endogenous performance variables (Y), has a direct relationship pattern, also has a significant indirect relationship pattern, namely IE through $\mathrm{X}_{3}=$ py3 p32 $(0.47 .0,34)=0.16$.

Third, the pattern of relations between ICT variable and performance variable $(\mathrm{Y})$. with the equation, $\mathrm{Y}=\mathrm{py} 3 \mathrm{X}_{3}+\mathrm{e} 5$. 
Obtained $\mathrm{DE}=$ not significant. Based on the results of the decomposition above, it shows that exogenous variables, ICT ability $\left(\mathrm{X}_{3}\right)$ do not have an indirect relationship pattern, nor a significant direct relationship pattern with performance.

Correlation decomposition above generates that the pattern of direct and indirect effects of exogenous variables is on the performance variables, which are briefly formulated in the table as follows.

\begin{tabular}{clccc}
\hline No & \multicolumn{1}{c}{ From Variable } & DE & IE & Total \\
\hline 1. & Self-efficacy $\left(\mathrm{X}_{1}\right)$ & 0,30 & 0,00 & 0,30 \\
\hline 2. & Perception $\left(\mathrm{X}_{2}\right)$ & 0,47 & 0,34 & 0,81 \\
\hline 3. & ICT Ability $\left(\mathrm{X}_{3}\right)$ & 0,00 & 0,00 & 0,00 \\
\hline 4. & $\mathrm{X}_{1}$ through $\mathrm{X}_{3}$ & 0,00 & 0,00 & 0,00 \\
\hline 5. & $\mathrm{X}_{2}$ through $\mathrm{X}_{3}$ & 0,16 & 0,00 & 0,16 \\
\hline
\end{tabular}

Based on the table above, it shows that the variable selfefficacy $\left(\mathrm{X}_{1}\right)$ only has a direct influence on teacher performance (Y), has no indirect influence. Perception variables have an indirect influence on performance, and also have a direct influence.

Then how much is the useful contribution of each $X$ variable to the variable $Y$ ? For searching for the useful contribution of each variable $\mathrm{X}$ is by multiplying the path coefficient (p) with the correlation coefficient (r). The path coefficient score $(p)$ is obtained from the table of decomposition of the causal relationship to the performance variable $(\mathrm{Y})$. while the correlation coefficient score is obtained through the correlation matrix as below.

\begin{tabular}{ccccc}
\hline Variable & $\mathbf{1}$ & $\mathbf{2}$ & $\mathbf{3}$ & $\mathbf{4}$ \\
\hline $\mathbf{1}$ & 1,000 & & & \\
\hline $\mathbf{2}$ & 0,318 & 1,000 & & \\
\hline $\mathbf{3}$ & 0,174 & 0,358 & 1,000 & \\
\hline $\mathbf{4}$ & 0,449 & 0,566 & 0,228 & 1,000 \\
\hline
\end{tabular}


Following the criterium, determining the useful contribution of each $\mathrm{X}$ variable is by entering the correlation coefficient score into a table of decomposition of the causal relationship to the performance variable, as below.

\begin{tabular}{clccc}
\hline No & From Variable & DE & IE & Total \\
\hline 1. & Self-efficacy & $0,30(0,45)$ & 0,00 & 0,14 \\
& $\left(\mathrm{X}_{1}\right)$ & $(0,14)$ & & \\
\hline 2. & Perception $\left(\mathrm{X}_{2}\right)$ & $\begin{array}{c}0,47(0,57) \\
0,27\end{array}$ & 0,34 & 0,61 \\
& & & \\
\hline 3. & ICT Ability $\left(\mathrm{X}_{3}\right)$ & $0,00(0,23)$ & 0,00 & 0,00 \\
\hline 4. & $\mathrm{X}_{1}$ through $\mathrm{X}_{3}$ & 0,00 & 0,00 & 0,00 \\
\hline 5. & $\mathrm{X}_{2}$ through $\mathrm{X}_{3}$ & 0,16 & 0,00 & 0,04 \\
& & & $(0,23)$ & \\
\hline
\end{tabular}

Table: Effective contribution to performance

The table shows that self-efficacy has an effective contribution to the direct effect on performance by $14 \%$. Self-efficacy has no contribution from the indirect effect on performance. Perception has an effective contribution from direct influence on the performance of $27 \%$ and also has an effective contribution from indirect effects of $34 \%$. Based on the results of effective contribution, as found in the table above, the conclusion is that $75 \%$ of the variation in teacher performance $(\mathrm{Y})$ can be predicted through a variety of variables X. The details are $14 \%$ self-efficacy, $27 \%$ through perception variable, 34\% through ICT ability variable, while the remaining $25 \%$ cannot be explained through the three exogenous variables. Other variables may explain some of the remaining effective contributions outside of the three variables, and 
others are variations due to measurement errors. Overall, the remaining $25 \%$ is called an error variable or residual or unexplained variance.

For proving the hypothesis formulated in this study is by explaining as follows. (1) The causal relationship between selfefficacy and teacher performance. Self-efficacy does not have a pattern of indirect influence with teacher performance, but has a significant direct influence pattern $(\mathrm{py} 1=0.30)$ and has an effective contribution of $0.14 \%$. That means that the variance of the performance of Islamic religious teachers that can be explained by the variable self-efficacy is only $14 \%$. Although having a small effective contribution, but this contribution means that selfefficacy is an important thing in improving the teacher's performance. (2) The causal relationship between perceptions and teacher performance variables. Perception has a pattern of direct influence with teacher performance (py2 $X_{2}=47 \%$ ), and also has a significant pattern of indirect influence through ICT ability variable (py2 p22 $=0.34 \%$ ) with an effective contribution of 0.61 $(61 \%)$. Based on these findings, the conclusion is that the perception variable turns out that the influence is stronger than selfefficacy. Perception has a direct influence on teacher performance, and can also influence ICT ability. This finding confirms that perception has a function on increasing the performance of Islamic religious teachers and can also be a predictor variable for the ICT ability.

Examining the results of the research shows some differences between the literature review and theoretical review with the empirical data. The theory said that self-efficacy is the influential variable for the teacher's performance, but the fact shows the different finding that self-efficacy gives a small contribution to performance. 


\section{Conclusion and Recommendation}

Based on the discussion above, the conclusions are selfefficacy and perception have proven as the couple variables for performance. Besides, the perception has determined the teachers using ICT in the classroom. In turn, the quality dan effectivity of improving the teacher's performance can be supported through enhancing self-efficacy and perception of the teachers. The finding of the research recommends that self-efficacy and perception of Islamic teachers are vital aspects in determining the quality of performance. The performance teacher's quality can be shown by using ICT in the classroom. Future research may wish to research the relationship of self-efficacy and perception to the performance of the Islamic teachers by using the qualitative design or mixed research design.

\section{Bibliography}

Alt, Dorit. "Science Teachers' Conceptions of Teaching and Learning, ICT Efficacy, ICT Professional Development, and ICT Practices Enacted in Their Classrooms." Teaching and Teacher Education 73 (July 2018): 141-50. https://doi.org/10.1016/j.tate.2018.03.020.

Althauser, Krista. "Job-Embedded Professional Development: Its Impact on Teacher Self-Efficacy and Student Performance." Teacher Development 19, no. 2 (April 2015): 210-25. https://doi.org/10.1080/13664530.2015.1011346.

Armstrong, Michael. Performance Management: Key Strategies and Practical Guidelines. 2nd ed. London: Kogan Page, 2000. Avery, Peter, ed. The contrast in Phonology: Theory, Perception, Acquisition. Phonology and Phonetics. Berlin [u.a.]; Mouton de Gruyter, 2008.

Bandura, Albert. Self-Efficacy: The Exercise of Control. 1st Ed. New York, NY, USA: W.H. Freeman \& Co., 1997. 
- ed. Self-Efficacy in Changing Societies. Reprint. Cambridge: Cambridge Univ. Press, 1999.

- "Social Cognitive Theory of Self-Regulation." Organizational Behavior and Human Decision Processes 50, no. 2 (1991): 248-87.

. Social Learning Theory. Englewood Cliffs, N.J: PrenticeHall, 1977.

Baron, Angela, and Michael Armstrong. Human Capital Management: Achieving Added Value through People. London; Philadelphia: Kogan Page Ltd, 2007.

Baş, Gökhan, Milan Kubiatko, and Ali Murat Sünbül. "Teachers' Perceptions towards ICTs in Teaching-Learning Process: Scale Validity and Reliability Study." Computers in Human Behavior $61 \quad$ (August 2016): 176-85. https://doi.org/10.1016/j.chb.2016.03.022.

Benes, Sarah, Kevin E Finn, Eileen C Sullivan, and Zi Yan. "Teachers' Perceptions of Using Movement in the Classroom." The Physical Educator 73, no. 1 (2016). https://doi.org/10.18666/TPE-2016-V73-I1-5316.

Bernacki, Matthew L, Timothy J Nokes-Malach, and Vincent Aleven. "Examining Self-Efficacy during Learning: Variability and Relations to Behavior, Performance, and Learning." Metacognition and Learning 10, no. 1 (April 2015): 99-117. https://doi.org/10.1007/s11409-014-9127-x.

Campbell, Conni, Carlos Cuauhtémoc Ayala, Gary Railsback, Frederick W Freking, Corey McKenna, and David Lausch. "Beginning Teachers' Perceptions of the California Teaching Performance Assessment (TPA)." Teacher Education Quarterly 43, no. 2 (2016): 51.

Celik, Vehbi, and Etem Yesilyurt. "Attitudes to Technology, Perceived Computer Self-Efficacy, and Computer Anxiety as Predictors of Computer Supported Education." Computers \& 
Education 60, no. 1 (January 2013): 148-58. https://doi.org/10.1016/j.compedu.2012.06.008.

Chang, Yu shan, Mavis Yi Ching Chen, Meng Jung Chuang, and Chia hui Chou. "Improving Creative Self-Efficacy and Performance through Computer-Aided Design Application." Thinking Skills and Creativity 31, no. September 2018 (2019): 103-11. https://doi.org/10.1016/j.tsc.2018.11.007.

Chesnut, Steven Randall, and Hansel Burley. "Self-Efficacy as a

Predictor of Commitment to the Teaching Profession: A Meta-Analysis." Educational Research Review 15 (June 2015): 1-16. https://doi.org/10.1016/j.edurev.2015.02.001.

Chong, Wan Har, Gregory Arief D Liem, Vivien S Huan, Phey Ling Kit, and Rebecca P Ang. "Student Perceptions of SelfEfficacy and Teacher Support for Learning in Fostering Youth Competencies: Roles of Affective and Cognitive Engagement." Journal of Adolescence 68 (October 2018): 111. https://doi.org/10.1016/j.adolescence.2018.07.002.

Cohen, J. Applied Multiple Regression/Correlation Analysis for the Behavioral Sciences. New Jersey: LEA: Inc, 1975.

Cohen, Louis, Lawrence Manion, and Keith Morrison. Research Methods in Education. 5th ed. London; New York: RoutledgeFalmer, 2000.

Comi, Simona Lorena, Gianluca Argentin, Marco Gui, Federica Origo, and Laura Pagani. "Is It the Way They Use It? Teachers, ICT, and Student Achievement." Economics of Education Review 56 (February 2017): 24-39. https://doi.org/10.1016/j.econedurev.2016.11.007.

Cunska, Aija, and Inga Savicka. "Use of ICT Teaching-Learning Methods Make School Math Blossom." Procedia - Social and Behavioral Sciences 69 (December 2012): 1481-88. https://doi.org/10.1016/j.sbspro.2012.12.089.

Ellis, Ralph D, and Natika Newton, eds. Consciousness \& 
Emotion: Agency, Conscious Choice, and Selective Perception. Consciousness \& Emotion Book Series. Amsterdam; Philadelphia: John Benjamins Publishing Company, 2005.

Ercikan, Kadriye, and Wolff-Michael Roth, eds. Generalizing from Educational Research: Beyond Qualitative and Quantitative Polarization. New York: Routledge, 2009.

Gaskill, Pamela J, and P Karen Murphy. "Effects of a Memory Strategy on Second-Graders' Performance and SelfEfficacy." Contemporary Educational Psychology 29, no. 1 (January 2004): 27-49. https://doi.org/10.1016/S0361476X(03)00008-0.

Good, Justin. Wittgenstein and The Theory of Perception. London ; New York: Continuum, 2006.

Hale, Judith A. Performance-Based Management: What Every Manager Should Do to Get Results. San Francisco: Pfeiffer, 2004.

Hayes, Debra, ed. Teachers \& Schooling Making a Difference: Productive Pedagogies, Assessment, and Performance. Studies in Education. Crows Nest: Allen \& Unwin, 2006.

Heuer, H, and Steven W Keele, eds. Handbook of Perception and Action, Volume 2: Motor Skills. London: Academic Press, Inc., 1996.

Honicke, Toni, and Jaclyn Broadbent. "The Influence of Academic Self-Efficacy on Academic Performance: A Systematic Review." Educational Research Review 17 (February 2016): 63-84. https://doi.org/10.1016/j.edurev.2015.11.002.

Hsu, Shihkuan. "Who Assigns the Most ICT Activities? Examining the Relationship between Teacher and Student Usage." Computers \& Education 56, no. 3 (April 2011): 847-55. https://doi.org/10.1016/j.compedu.2010.10.026.

Jones, Michael D. "Teacher Behavior under Performance Pay 
Incentives." Economics of Education Review 37 (December 2013): 148-64.

https://doi.org/10.1016/j.econedurev.2013.09.005.

Kerckaert, Stephanie, Ruben Vanderlinde, and Johan van Braak. "The Role of ICT in Early Childhood Education: Scale Development and Research on ICT Use and Influencing Factors." European Early Childhood Education Research Journal 23, no. 2 (March 2015): 183-99. https://doi.org/10.1080/1350293X.2015.1016804.

Klassen, Robert M, and Virginia M C Tze. 'Teachers' SelfEfficacy, Personality, and Teaching Effectiveness: A MetaAnalysis." Educational Research Review 12 (June 2014): 5976. https://doi.org/10.1016/j.edurev.2014.06.001.

Komarraju, Meera, and Dustin Nadler. "Self-Efficacy and Academic Achievement: Why Do Implicit Beliefs, Goals, and Effort Regulation Matter?" Learning and Individual Differences 25 (June 2013): 67-72. https://doi.org/10.1016/j.lindif.2013.01.005.

Kopcha, Theodore J. "Teachers' Perceptions of the Barriers to Technology Integration and Practices with Technology under Situated Professional Development." Computers \& Education 59, no. 4 (December 2012): 1109-21. https://doi.org/10.1016/j.compedu.2012.05.014.

Kreijns, Karel, Frederik Van Acker, Marjan Vermeulen, and Hans van Buuren. "What Stimulates Teachers to Integrate ICT in Their Pedagogical Practices? The Use of Digital Learning Materials in Education." Computers in Human Behavior 29, no. 1 (January 2013): https://doi.org/10.1016/j.chb.2012.08.008.

Kung, Hsin-Yi. "Perception or Confidence? Self-Concept, SelfEfficacy, and Achievement in Mathematics: A Longitudinal Study." Policy Futures in Education 7, no. 4 (August 2009): 
387-98. https://doi.org/10.2304/pfie.2009.7.4.387.

Leavy, Patricia. Research Design: Quantitative, Qualitative, Mixed Methods, Arts-Based, and Community-Based Participatory Research Approaches. New York, NY, USA: The Guilford Press, 2017.

Lim, Sungtaek, and Sungmin Eo. "The Mediating Roles of Collective Teacher Efficacy in the Relations of Teachers' Perceptions of School Organizational Climate to Their Burnout." Teaching and Teacher Education 44 (November 2014): 138-47. https://doi.org/10.1016/j.tate.2014.08.007.

Mercer, Justine, Bernard Barker, and Richard Bird. Human Resource Management in Education: Contexts, Themes, and Impact. Leadership for Learning Series. London; New York: Routledge, 2010.

Mertens, Donna M. Research and Evaluation in Education and Psychology: Integrating Diversity with Quantitative, Qualitative, and Mixed Methods. 3rd ed. Los Angeles: Sage, 2010.

Miller, Angela D, Erin M Ramirez, and Tamera B Murdock. "The Influence of Teachers' Self-Efficacy on Perceptions: Perceived Teacher Competence and Respect and Student Effort and Achievement." Teaching and Teacher Education 64 (May 2017): 260-69. https://doi.org/10.1016/j.tate.2017.02.008.

Mura, Giulia, and Davide Diamantini. "The Use and Perception of ICT among Educators: The Italian Case." Procedia - Social and Behavioral Sciences 141 (August 2014): 1228-33. https://doi.org/10.1016/j.sbspro.2014.05.211.

Niedenthal (Editor), Paula M. The Heart's Eye: Emotional Influences in Perception and Attention. San Diego, California: Academic Press, Inc., 1994.

Niedenthal, Paula M, and Shinobu Kitayama, eds. The Heart's Eye, 
Emotional Influence in Perception and Attention. San Diego, California: Academic Press, Inc., 1994.

Oko, BA, and L Uwatt. "ICT and Teachers' Performance in Terms of Lesson Preparation and Delivery in Primary Schools in Ogoja Education Zone of Cross River State, Nigeria." Global Journal of Educational Research 14, no. 2 (2015): 87. https://doi.org/10.4314/gjedr.v14i2.2.

Oliver, Regina M., Joseph H. Wehby, and J. Ron Nelson. "Helping

Teachers Maintain Classroom Management Practices Using a Self-Monitoring Checklist." Teaching and Teacher Education 51 (2015): 113-20.

https://doi.org/10.1016/j.tate.2015.06.007.

Owston, Ron, Dennis York, and Susan Murtha. "Student Perceptions and Achievement in a University Blended Learning Strategic Initiative." The Internet and Higher Education 18 (July 2013): 38-46. https://doi.org/10.1016/j.iheduc.2012.12.003.

Pedhazur, Elazar J. Multiple Regression in Behavioral Research:

Explanation and Prediction. 3rd ed. Forth Worth: Harcourt Brace College Publishers, 1997.

Pedhazur, Elazar J, and Liora Pedhazur Schmelkin. Measurement, Design, and Analysis: An Integrated Approach. Hillsdale, N.J: Lawrence Erlbaum Associates, 1991.

Raab, Markus, Babett Helen Lobinger, Sven Hoffmann, Alexandra Pizzera, and Sylvain Laborde, eds. Performance Psychology: Perception, Action, Cognition, and Emotion. London: Elsevier Academic Press, 2016.

Reyes, Cynthia, and Kathleen Brinegar. "Lessons Learned: Using the Literacy Histories of Education Students to Foster Empathy." Teaching and Teacher Education 59 (October 2016): 327-37. https://doi.org/10.1016/j.tate.2016.06.014.

Rohatgi, Anubha, Ronny Scherer, and Ove E Hatlevik. "The Role 
of ICT Self-Efficacy for Students' ICT Use and Their Achievement in a Computer and Information Literacy Test." Computers \& Education 102 (November 2016): 103-16. https://doi.org/10.1016/j.compedu.2016.08.001.

Rookes, Paul, and Jane Willson. Perception: Theory, Development, and Organisation. Routledge Modular Psychology. London; New York: Routledge, 2000.

Skaalvik, Einar M, and Sidsel Skaalvik. "Teacher Self-Efficacy and Teacher Burnout: A Study of Relations." Teaching and Teacher Education 26, no. 4 (May 2010): 1059-69. https://doi.org/10.1016/j.tate.2009.11.001.

Smither, James W, and Manuel London, eds. Performance Management: Putting Research into Action. The Professional Practice Series. San Francisco: Jossey-Bass, 2009.

Swainston, Tony. Effective Teachers in Secondary Schools: A Reflective Resource for Performance Management. 2nd ed. London: New York: Continuum International Pub. Group, 2008. www.networkcontinuum.co.uk

www.continuumbooks.com.

Teo, Timothy, ed. Handbook of Quantitative Methods for Educational Research. Rotterdam: SensePublishers, 2013.

Webb, Mary, and Roshaunda Thomas. "Teachers' Perceptions of Educators' and Students' Role in Closing the Achievement Gap" 25, no. 3 (2015): 8.

Wentzel, Kathryn R, and Allan Wigfield, eds. Handbook of Motivation at School. Educational Psychology Handbook Series. New York; London: Routledge, 2009.

Yazdi, Mona Tabatabaee, Khalil Motallebzadeh, and Hamid Ashraf. "The Role of Teacher's Self-Efficacy as a Predictor of Iranian EFL Teacher's Burnout." Journal of Language Teaching and Research 5, no. 5 (September 2014): 11981204. https://doi.org/10.4304/jltr.5.5.1198-1204. 